\title{
Cellular coating of the left ventricular assist device textured polyurethane membrane reduces adhesion of Staphylococcus aureus
}

Tomohiro Asai, MD, ${ }^{\text {a }}$ Mei-Ho Lee, ${ }^{\text {b }}$ Carlos Arrecubieta, PhD, ${ }^{\text {b }}$ Manuel Prinz von Bayern, ${ }^{\text {b } C h r i s t i a n ~ A . ~ C e s p e d e s, ~}{ }^{\text {b }}$ Helen M. Baron, MD, ${ }^{\mathrm{b}}$ Martin Cadeiras, MD, ${ }^{\mathrm{b}}$ Taichi Sakaguchi, MD, ${ }^{\mathrm{a}}$ Charles C. Marboe, MD, ${ }^{\mathrm{c}}$ Yoshifumi Naka, MD, PhD, ${ }^{a}$ Mario C. Deng, MD, ${ }^{b}$ and Franklin D. Lowy, MD ${ }^{\text {b,c }}$

From the Departments of Surgery, ${ }^{a}$ Medicine, ${ }^{\mathrm{b}}$ and Pathology, ${ }^{\mathrm{c}}$ New York Presbyterian Hospital, College of Physicians \& Surgeons, Columbia University, New York, NY.

Supported by the National Heart, Lung, and Blood institute (NHLBI) Specialized Center for Clinically Oriented Research (SCCOR) grant HL 077096-01, named "The Biology of Human Long-Term Mechanical Circulatory Support," and by The Health Research Board program grant PRO 09/2002.

Received for publication June 14, 2006; revisions received Oct 7, 2006; accepted for publication Oct 25, 2006

Address for reprints: Mario C. Deng, MD, FACC, FESC, Director of Cardiac Transplantation Research, Department of Medicine, Columbia University College of Physicians \& Surgeons, New York, NY 10032 (E-mail: md785@columbia.edu).

J Thorac Cardiovasc Surg 2007;133:1147-53 $0022-5223 / \$ 32.00$

Copyright (C) 2007 by The American Association for Thoracic Surgery

doi:10.1016/j.jtcvs.2006.10.084
Objective: Infections are among the most common and serious complications of ventricular assist device implantation. These infections generally occur within the first 2 months after surgery. The basis for this high incidence of infection is not well established, so a murine intravascular infection model was developed with aortic implantation of the textured polyurethane patch material currently used in HeartMate ventricular assist devices (Thoratec Corporation Pleasanton, Calif).

Methods: Polyurethane patch material was placed in the wall of the mouse descending aorta. Mice were then infected with Staphylococcus aureus 1 or 14 days after implantation. In vitro adhesion studies were conducted with polyurethane membranes coated with endothelial cells and membranes coated with fibrinogen.

Results: Mice were susceptible to infection in both dose- and time-dependent fashions. The patch material was significantly more susceptible to infection at day 1 than day 14. Immunohistologic and morphologic studies demonstrated that the $\mathrm{CD} 1^{+}$cells deposited on the membrane surface phenotypically appeared to be endothelial cells. In vitro adhesion studies of polyurethane membranes coated with endothelial cells showed them to be less susceptible to $S$ aureus binding than were membranes coated with fibrinogen.

Conclusion: Textured polyurethane membranes are less susceptible to infection as cellular deposition occurs. The time frame within which these membranes become populated with cellular material is consistent with the time-dependent clinical incidence of infection. Cellular coating of polyurethane may provide a strategy for reducing the risk of infection.

$\mathrm{M}$ echanical circulatory support devices, specifically left ventricular assist devices (LVADs), are a major form of therapy for patients with advanced heart failure. ${ }^{1}$ Originally introduced as a bridge to cardiac transplantation, they have recently been approved as destination therapy for patients with end-stage heart failure who are ineligible for cardiac transplantation. LVADs improve survival and quality of life for patients with advanced heart failure who are ineligible for transplantation ${ }^{2}$; however, a serious limitation to the long-term use of LVADs has been the high incidence of device-related infections. ${ }^{3-6}$ These infections, ranging from driveline infections to device-associated endocarditis, occur in $20 \%$ to $50 \%$ of patients and cause significant morbidity and mortality. A combination of factors is believed to be responsible for the high incidence of life-threatening infection, including the immunocompromised host, the presence of a transcutaneous driveline, the numerous invasive procedures performed on these patients, and the presence of a large prosthetic device. 


\section{Abbreviations and Acronyms \\ $\mathrm{CFU}=$ colony-forming units \\ $\mathrm{LVAD}=$ left ventricular assist device \\ POD = postoperative day}

Staphylococcus aureus is among the most common of the pathogens that are associated with LVAD-related infections. ${ }^{3-6}$ We therefore elected to use $S$ aureus to investigate the pathogenesis of LVAD-related endovascular infections, focusing on the initial colonization step in which bacteria adhere to the neointimal lining that forms on the surface of the textured HeartMate (Thoratec Corporation Pleasanton, Calif) LVAD polyurethane membrane. These membranes have already been shown to reduce the incidence of thromboembolic complications associated with LVAD implantation. ${ }^{7}$ To mimic the clinical situation, we developed an in vivo murine aortic polyurethane patch model. ${ }^{8}$ In this model, the blood-contacting surface of the membrane was coated with cellular material in a time-dependent manner. With this model, we aimed to establish an animal model of LVAD-associated infection and to determine the effect of cellular population on the susceptibility of the polyurethane patch to $S$ aureus infection.

\section{Materials and Methods \\ Polyurethane Patch Material}

Polyurethane patch material was provided by Thoratec Corporation, the makers of the HeartMate LVAD. Except for its thickness $(0.125 \mathrm{~mm})$, the patch material was identical to the material used for the inner surface of the HeartMate LVAD. The patch size was $1 \times 4 \mathrm{~mm}$.

\section{Animals}

Male C57BL/6J mice from 3 to 4 months old (Jackson Laboratories, Bar Harbor, Mass) were maintained for at least a week on a light-dark (12 hour/12 hour) cycle at $25^{\circ} \mathrm{C}$ before the experiment. All procedures were performed according to protocols approved by the Columbia University Institutional Animal Care and Use Committee.

\section{Patch Implantation Procedure}

The polyurethane patch was implanted in the mouse abdominal aorta as described previously. ${ }^{8}$ Briefly, the mice were anesthetized by intraperitoneal injection of ketamine and xylazine. An intraperitoneal injection of heparin $(300 \mathrm{IU} / \mathrm{kg}$ ) was given before the procedure. The abdomen was opened through a midline incision, and the abdominal aorta and the inferior vena cava were exposed and carefully freed. The segment of the abdominal aorta between the renal arteries and the aortic bifurcation was temporally occluded with microvascular clamps (Roboz Surgical Instrument Co, Inc, Gaithersburg, Md), and the aorta was cut open longitudinally. A sterile, polyurethane membrane patch (HeartMate) was sewn onto the aorta with 10-0 nylon running suture around the margin of the patch under $25 \times$ magnification (Leitz Wild microscope M651; Wild Surgical Microscopes Co, Heerbrugg, Switzerland). After the vascular clamp was removed, pulsatile flow was confirmed at the distal part of the aorta. The operative field was irrigated with saline solution, and the skin incision was closed. Buprenorphine was given subcutaneously for postoperative analgesia as necessary. The animal was given $1 \mathrm{~mL}$ normal saline solution subcutaneously and put into a $36^{\circ} \mathrm{C}$ incubator for recovery. The entire procedure took approximately 45 minutes.

\section{In Vivo Infection Model}

$S$ aureus (Wb strain), an endocarditis isolate, was used in this study. ${ }^{9,10}$ Susceptibility to infection was determined in a series of dose escalation studies. One day after patch implantation, the mice were lightly anesthetized and received a tail vein injection concentration of $10^{6}, 10^{7}$, or $10^{8}$ colony-forming units (CFU) of $S$ aureus $(0.2 \mathrm{~mL})$. A blood sample was obtained to confirm bacteremia 1 hour after inoculation. After infection, the mice were kept in different cages to avoid cross infection. The mice were killed 3 days after infection. Liver, kidneys, spleen, and the polyurethane patch were excised for bacterial assay. The tissue was washed in phosphate-buffered saline solution, weighed, and homogenized in phosphate-buffered saline solution; aliquots of the homogenate were then plated onto mannitol salt agar plates (Becton Dickinson Microbiology Systems, Sparks, Md). Each plate was incubated for 24 hours at $37^{\circ} \mathrm{C}$, and the number of colonies was determined. Results were expressed as the CFU per gram of tissue.

Susceptibility to infection was also assessed across time. These studies were performed to test the hypothesis that time-dependent changes in polyurethane topology alter the susceptibility to infection. The mice were infected either 1 day or 14 days after patch implantation. After infection, the mice were processed in the same manner as outlined for the dose escalation studies. Because dose escalation and time dependencies were our variables of interest in the context of this study, the time point at which the animals were killed (3 days) was kept constant.

\section{Histologic Studies}

After they had been humanely killed, mice infected with $S$ aureus 1 day after polyurethane patch implantation were perfused with phosphate-buffered saline solution through a cardiac puncture in the left ventricle at physiologic pressure with an infusion pump. The aorta, including the patch, was excised from the body, embedded in OCT freezing compound (Sakura Finetek USA, Inc, Torrance, Calif), frozen, and stored at $-80^{\circ} \mathrm{C}$. Transverse sections $(8 \mu \mathrm{m})$ from the middle of the polyurethane patch were stained with hematoxylin and eosin or Gram stain.

\section{In Vitro Assay Measuring Effect of Endothelial Cell Coating of Polyurethane Membranes on} $S$ Aureus Adhesion

An in vitro assay was developed to assess further the role of endothelialization in reducing bacterial adhesion to the polyurethane membrane. Endothelial cells (Cambrex Corporation, East Rutherford, NJ) were grown to confluence in endothelial cell growth medium. ${ }^{9}$ Adhesion of $S$ aureus to fibrinogen- versus endothelial cell-coated membranes was then compared with a modification of a previously described adhesion assay. ${ }^{9,11}$ LVAD 
membrane (diameter $0.5 \mathrm{~cm}$ ) was immobilized on the bottom of a 96-well tissue culture dish (Becton, Dickinson and Company, Franklin Lakes, NJ). Fibrinogen $(0.5 \mathrm{mg} / \mathrm{mL}$; Sigma, St Louis, Mo) was added to the membrane-containing wells and incubated overnight at $37^{\circ} \mathrm{C}$. The next day wells were washed, seeded with endothelial cells, and incubated in endothelial cell growth media at $37^{\circ} \mathrm{C}$ in $5 \%$ carbon dioxide for an additional 2 days.

$S$ aureus (Wb strain) was grown overnight in Todd Hewitt broth (Becton Dickinson). The next morning, an aliquot from the overnight sample was diluted and reincubated for 3 hours to bring the suspension to logarithmic growth phase. The sample was then centrifuged and resuspended in $2 \mathrm{~mL}$ M199 Earle Salts (Invitrogen Corporation, Carlsbad, Calif), and the suspension was adjusted to an optical density at $600 \mathrm{~nm}$ of 0.01 .

The membrane-containing microtiter wells were washed once with Medium 199 (Invitrogen). The staphylococcal suspension was vortex mixed, and $100 \mu \mathrm{L}$ was added to the membranes coated with either endothelial cells or fibrinogen. The microtiter plate was incubated at $37^{\circ} \mathrm{C}$ for 1 hour. The bacterial suspensions were then aspirated and the wells washed with Medium 199 at $37^{\circ} \mathrm{C}$ for 5 minutes at $80 \mathrm{rpm}$. The bacteria and cells were lifted with trypsinethylenediaminetetraacetic acid (Invitrogen). The number of endothelial cells per well was determined with a hemocytometer. Aliquots $(100 \mu \mathrm{L})$ of the trypsin-digested samples were plated onto heart infusion Agar (Becton Dickinson) and incubated overnight at $37^{\circ} \mathrm{C}$. The colonies grown in the plates were counted, and the results were expressed as the number of bacteria per well. Each assay was performed with 12 wells per condition and was repeated four times.

\section{Statistical Analysis}

Data were compared with an unpaired Student $t$ test.

\section{Results}

\section{Murine Infection Model}

The mouse surgical survival rate was $77.5 \%$, and the patency of the aorta was $100 \%$. There were no unexpected deaths perioperatively before bacterial inoculation. All mice infected with a bacterial inoculum of $10^{8} \mathrm{CFU}(\mathrm{n}=8)$ died within 24 hours. These animals were severely ill, exhibiting signs of inactivity, sweating, shivering. All animals infected with $10^{6}$ or $10^{7} \mathrm{CFU}$ survived. The animals in these groups also showed signs of illness with inactivity and sweating but did not appear as ill as the animals in the group infected with $10^{8} \mathrm{CFU}$. Two of 7 mice in the $10^{6} \mathrm{CFU}$ group were not bacteremic at 1 hour, whereas all animals in the $10^{7}$ CFU group were bacteremic. Mice infected with $10^{7} \mathrm{CFU}$ had a higher grade of bacteremia than those infected with $10^{6} \mathrm{CFU}\left(10^{6} \mathrm{CFU}\right.$ vs $10^{7} \mathrm{CFU} 0.6 \pm 0.6$ vs $2.5 \pm 0.2, P<$ $.001)$.

Dose-dependence assay. Five of 7 polyurethane patches obtained from the mice infected with $10^{6} \mathrm{CFU}$ were sterile. All samples obtained from animals inoculated at $10^{7} \mathrm{CFU}$ were infected $\left(10^{6} \mathrm{CFU}\right.$ vs $10^{7} \mathrm{CFU} 1.1 \pm 1.9$ vs $6.8 \pm 1.2$, $P<.001$; Figure 1, $A$ ). The kidney and liver homogenates were all infected, regardless of the concentration of the
A

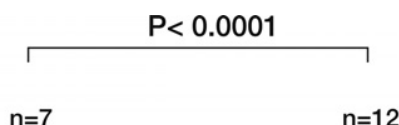

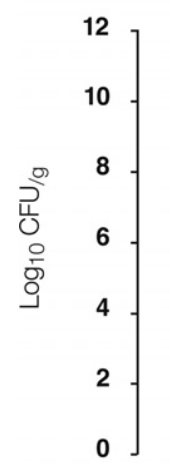

$\mathrm{n}=7$

$\mathrm{n}=12$

B

10

$\left.\begin{array}{l}12 \\ 10 \\ 8 \\ 6 \\ 4 \\ 2 \\ 0\end{array}\right]$

$10^{6}$

$10^{7}$
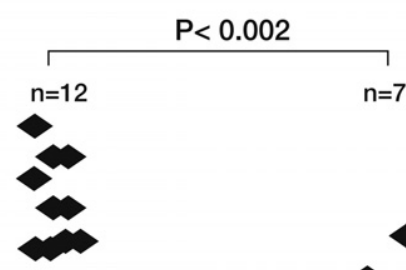

$\mathrm{n}=7$

1 pod

14 pod

Figure 1. Bacterial density on surface of polyurethane membrane 3 days after inoculation. A, Animals were inoculated with different concentrations of $S$ aureus $\left(10^{6}\right.$ and $10^{7}$ colony-forming units [CFU]/mouse). B, Animals were infected days 1 and 14 after polyurethane patch implantation. pod, Postoperative day.

inoculation. One spleen sample in the $10^{6} \mathrm{CFU}$ group was sterile. The organ bacterial density was higher in groups infected with the higher bacterial inoculum $\left(10^{6} \mathrm{CFU}\right.$ vs $\left.10^{7} \mathrm{CFU}\right)$ : kidneys, $4.6 \pm 2.1$ versus $6.5 \pm 0.6(P<.05$; Figure 2, $A)$; liver, $3.4 \pm 0.7$ versus $6.2 \pm 0.8(P<.001$; Figure $2, B)$; and spleen, $2.9 \pm 1.2$ versus $5.1 \pm 1.6(P<$ .002; Figure 2, C).

Time-dependence assay. For these experiments an inoculum of $10^{7} \mathrm{CFU}$ was used to achieve $100 \%$ infection at 1 day after polyurethane patch implantation. All animals were bacteremic 1 hour after infection. There was no difference in bacterial density between the two groups (postoperative day [POD] 1 vs POD $142.5 \pm 0.2$ vs $2.5 \pm 0.1, P=.46$ ).

All tissue samples obtained from mice infected POD 1 $(n=7)$ showed infection, whereas only 2 of 7 samples 

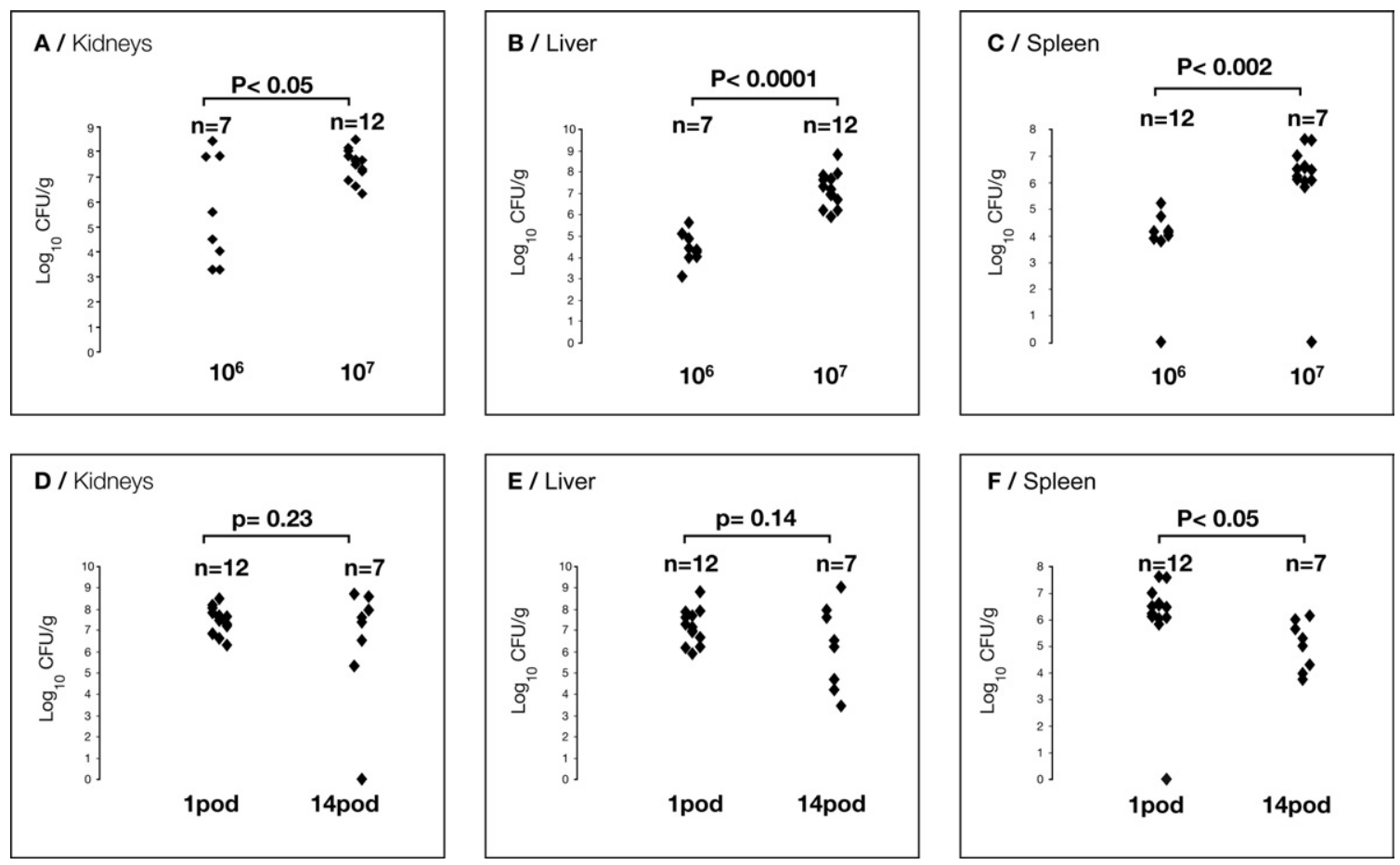

Figure 2. Bacterial density in organs 3 days after infection with $S$ aureus. A-C, Animals were inoculated with different concentrations of $S$ aureus $\left(10^{6}\right.$ and $10^{7}$ colony-forming units [CFU]/mouse). D-F, Animals were infected days 1 and 14 after polyurethane patch implantation. pod, Postoperative day.

from mice infected POD $14(\mathrm{n}=12)$ were infected. The bacterial densities in the patches from mice infected POD 1 were significantly higher than in those from mice infected POD 14 (POD 1 vs POD $146.8 \pm 1.2$ vs $1.77 \pm$ $2.7, P<.002$; Figure $1, B)$.

There was no difference in the bacterial density of homogenates from the kidneys and livers between the two groups. The number of bacteria in the spleen was lower in the POD 14 group: kidneys, POD 1 vs POD 14, $6.5 \pm 0.6$ versus $5.6 \pm 0.5(P=.23$; Figure $2, D)$; liver, POD 1 versus POD 14, $6.2 \pm 0.8$ versus $5.2 \pm 2.0(P=.14$; Figure $2, E)$; and spleen, POD 1 versus POD 14, $5.1 \pm 1.6$ versus $4.0 \pm$ $0.9(P<.05$; Figure $2, F)$.

\section{Histologic Studies}

One day after implantation, the polyurethane membrane was covered with a homogeneous fibrin layer (Figure 3, A, and Figure 4, A). Some of the fibers remained uncoated and in contact with the circulation. Polymorphonuclear leukocytes and mononuclear cells were attached to the surface as well as embedded within the fibrin (Figure 3,A). Sections obtained from an animal infected with $10^{7} \mathrm{CFU} 1$ day after implantation and killed at 3 days showed infiltration of the aortic wall with polymorphonuclear leukocytes in addition to the findings in the noninfected animals (Figure 3, B).
Gram-positive cocci were also observed in this tissue. Some of the bacteria were attached directly to the fibers of the polyurethane material, whereas some were seen embedded in the fibrin layer (Figure 3,C). At day 14, the bloodcontacting surface of the polyurethane membrane was totally covered with $\mathrm{CD} 31^{+}$cells; the morphology, location, and CD31 staining all suggest that these were endothelial cells (Figure 4, $B$ and $C$ ).

\section{In Vitro Assay Measuring Effect of Endothelial Cell Coating of Polyurethane Membranes on $S$ aureus Adhesion}

The initial bacterial inoculum used in these in vitro assays was $1.5 \pm 0.5 \times 10^{5} \mathrm{CFU} /$ well. The average number of endothelial cells adherent to the polyurethane membrane surface was $4.1 \pm 0.3 \times 10^{3}$ cells/well. There was a 10 -fold decrease in the number of $S$ aureus organisms adherent to the surface of the polyurethane membrane coated with $\mathrm{CD} 31^{+}$cells relative to membrane coated with fibrinogen, suggesting that the $\mathrm{CD} 31^{+}$cells created a barrier protecting the patch from infection (Figure 5).

\section{Discussion}

In this study, we report the development of a reproducible LVAD murine model of aortic patch infection. The 


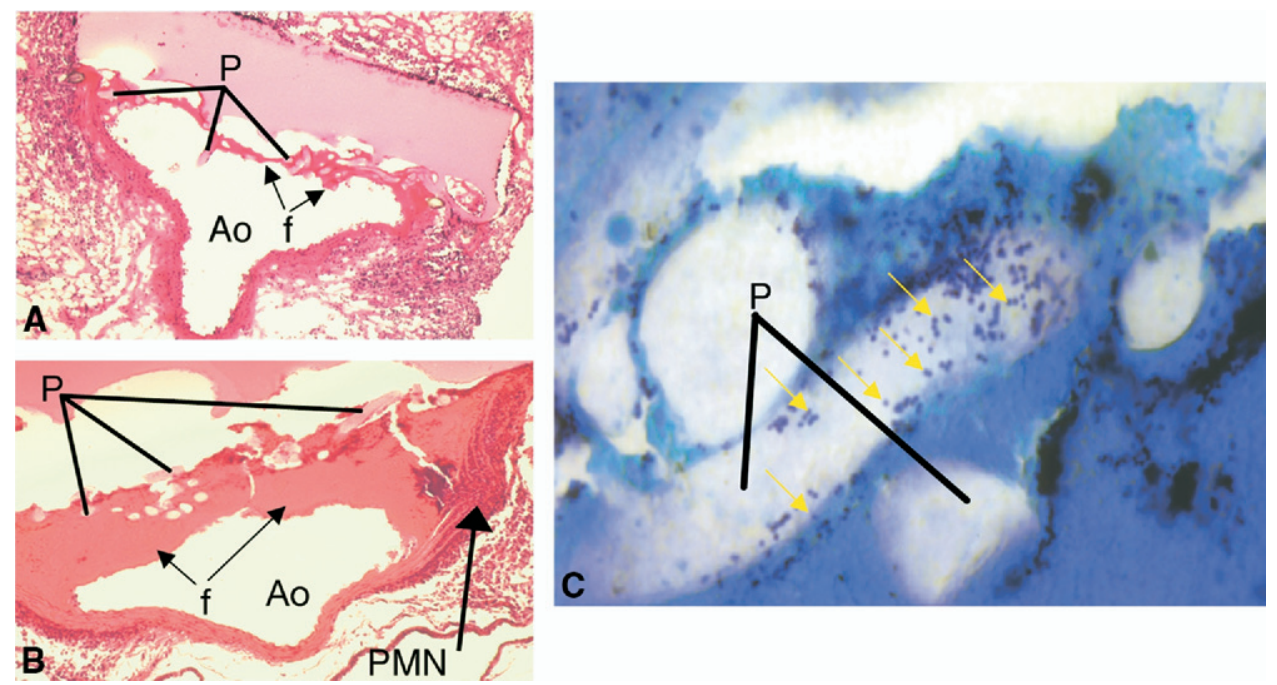

Figure 3. A, Representative cross-section of aorta $(A o) 1$ day after polyurethane patch $(P)$ implantation, covered with thin fibrin (f) layer (hematoxylin-eosin staining, original magnification $\times 50$ ). $B$, Representative cross-section of aorta $(A o) 4$ days after polyurethane patch $(P)$ implantation, covered with thick fibrin (f) layer. Animal was infected 1 day after implantation (hematoxylin-eosin staining, original magnification $\times 50$ ) PMN, Polymorphonuclear cells. C, Cross-section obtained from same infected animal was Gram stained $\left(10^{7}\right.$ colony-forming units, original magnification $\times 1000)$. Arrows indicate gram-positive cocci. $P$, Polyurethane patch.

model used textured polyurethane patch material from the HeartMate LVAD implanted into the mouse descending aorta. There was $100 \%$ survival of the mice after patch placement, as well as maintenance of pulsatile blood flow. This model allowed investigation of the parameters that influence the susceptibility of this material to subsequent infection. With $S$ aureus, one of the most common pathogens in LVAD infections, we found
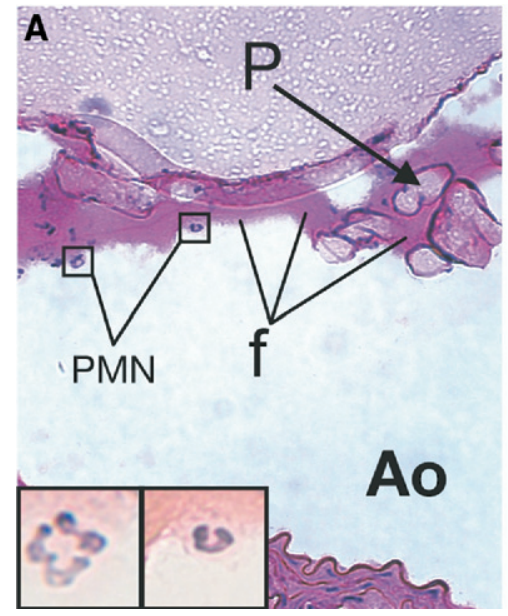

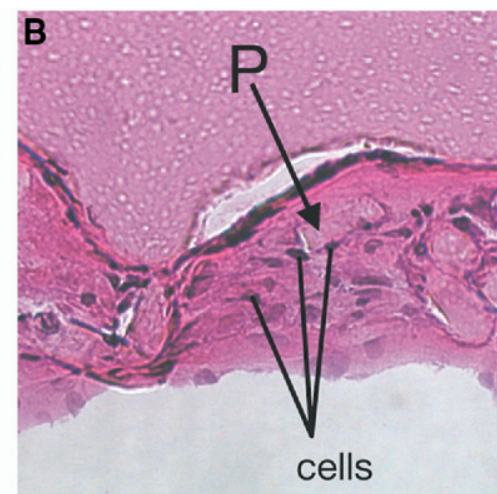

Ao

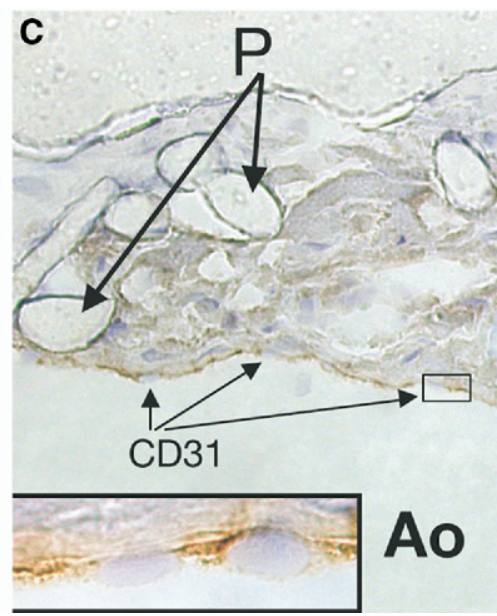

Figure 4. A, Hematoxylin-eosin staining of representative section of implanted polyurethane membrane (P) 1 day after implantation in aorta (Ao). Blood-contacting surface of polyurethane membrane is covered with thin layer of fibrin (f), and polymorphonuclear cells (PMN) are embedded with fibrin. Inserts show polymorphonuclear leukocytes. B, Hematoxylin-eosin staining of representative section of implanted polyurethane membrane $(P) 14$ days after implantation in aorta (Ao). Blood-contacting surface of polyurethane membrane is covered with cells. C, CD31 staining of representative section of implanted polyurethane membrane (P) 14 days after implantation in aorta (Ao) reveals cells on luminal surface to be $\mathrm{CD}^{+}{ }^{+}$(arrows). This suggests that after 14 days polyurethane membrane has been covered with protective cell layer. These findings were consistent for all animals examined ( $n=4$ in each group; original magnification $\times 200$ ). Insert shows $1000 \times$ magnification of $\mathrm{CD}_{31}{ }^{+}$cells. 


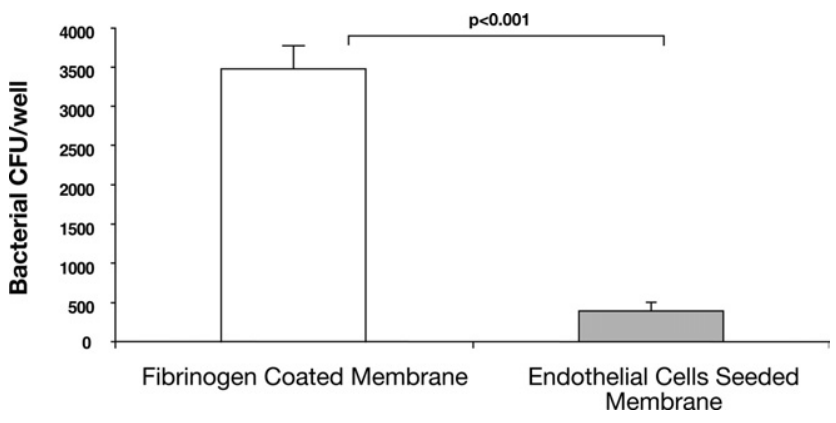

Figure 5. In vitro assay. Polyurethane membranes were fixed to 96-well tissue culture dishes and coated with fibrinogen. Half of membranes were subsequently coated with human endothelial cells and grown to confluence. Wh strain $S$ aureus was added to wells, and adhesion assay was performed. CFU, Colony-forming units.

both dose- and time-dependent susceptibilities to infection. The patch material was significantly more susceptible to infection at 1 day after implantation than 14 days. The histologic and in vitro studies provide a rationale for this altered susceptibility, the coating of the patch membrane surface with a cellular monolayer over time.

Textured surface polyurethane material was originally developed for clinical use to minimize the thromboembolic events that were frequently seen in patients who received devices with a smooth blood-contacting surface. In comparison, devices with a textured blood-contacting surface (eg, the HeartMate device) had a decreased rate of thromboembolic events, presumably as a result of the formation of a neointima. ${ }^{7}$ Because the polyurethane membranes were less susceptible to infection on day 14 , when the patch was coated with $\mathrm{CD} 31^{+}$cells, we hypothesize from results in this study that the neointima was also the basis for the protection against $S$ aureus infection. The results from the in vitro assay provide further support for this hypothesis.

The reduced susceptibility to infection with time in our animal model is also consistent with the results of clinical studies of LVAD infections. These studies demonstrate that most bacterial infections occur within 2 months of device implantation. ${ }^{3,5,12}$ Although there are several potential reasons for this, the absence of a cellular lining to the polyurethane membrane is one likely contributing factor. In a related in vitro study, Arrecubieta and colleagues ${ }^{23}$ demonstrated that LVAD polyurethane membranes explanted from patients after 6 months were significantly less susceptible to $S$ aureus adhesion than LVADs explanted earlier than 6 months.

The nature of the cellular lining of LVAD membranes evolves with time but has been found to include pluripotent $\mathrm{CD} 34^{+}$hematopoietic cells, endothelial cells, macrophages, fibroblasts, monocytes, and smooth muscle cells. ${ }^{13-16}$ These cells eventually establish a protective barrier, reducing exposure to the fibrinogen and fibrin deposited on the membrane surface shortly after implantation. As a result, the susceptibility to infection is reduced.

The cells lining the patch were $\mathrm{CD} 31^{+}$and had the morphologic appearance of endothelial cells. The identity of these cells as endothelial cells was not, however, confirmed by another immunohistochemical marker. The contribution of endothelial cells to the onset of endovascular infections is dichotomous. On the one hand, endothelial cells provide a continuous, protective barrier preventing access of bacteria to underlying tissue. In this study, the aortic polyurethane patch lined with $\mathrm{CD} 31^{+}$cells appeared less susceptible to infection than patch material coated with matrix molecules such as fibrinogen. Previous studies, however, have also demonstrated that $S$ aureus is capable of direct adhesion to endothelial cells. ${ }^{11,17,18}$ This binding appears to primarily occur through the $S$ aureus surface proteins fibronectinbinding proteins $\mathrm{A}$ and $\mathrm{B}$. These proteins are part of a family of structurally related proteins designated microbial surface components recognizing adhesive matrix molecules. ${ }^{19}$ These molecules are capable of adhering to matrix and cellular surfaces though a number of different receptorligand interactions. ${ }^{17,20}$

Our hypothesis is that fibrinogen, a serum component known to be deposited on prosthetic surfaces shortly after implantation, is more susceptible to $S$ aureus adhesion than is a cellular layer. Reduction of exposure to fibrinogen by cellular deposition reduces $S$ aureus adhesion. Several proteins mediate adhesion to fibrinogen, including the fibronectin-binding proteins and clumping factors $\mathrm{A}$ and $\mathrm{B}$. The additional variable of different parameters of flow has to date received limited attention; however, it does appear to affect the adhesion interaction. ${ }^{21}$

In conclusion, in our polyurethane aortic patch model of infection, the blood-contacting surface is covered with $\mathrm{CD} 31^{+}$cells with time. In addition to preventing thromboembolism, this textured membrane therefore achieves an element of protection from bacterial infection by rapid cell coating. This provides a potential strategy for future devices in reducing the incidence of bacterial infections, which constitute a major complication of LVAD use..$^{22,24}$

\section{References}

1. Hunt SA, Baker DW, Chin MH, Cinquegrani MP, Feldman AM, Francis GS, et al. ACC/AHA Guidelines for the Evaluation and Management of Chronic Heart Failure in the Adult: Executive Summary. A Report of the American College of Cardiology/American Heart Association Task Force on Practice Guidelines (Committee to Revise the 1995 Guidelines for the Evaluation and Management of Heart Failure): Developed in Collaboration With the International Society for Heart and Lung Transplantation; Endorsed by the Heart Failure Society of America. Circulation. 2001;104:2996-3007.

2. Rose EA, Gelijns AC, Moskowitz AJ, Heitjan DF, Stevenson LW, Dembitsky W, et al. Long-term mechanical left ventricular assistance for end-stage heart failure. N Engl J Med. 2001;345:1435-43. 
3. Herrmann M, Weyand M, Greshake B, von Eiff C, Proctor RA, Scheld $\mathrm{HH}$, et al. Left ventricular assist device infection is associated with increased mortality but is not a contraindication to transplantation. Circulation. 1997;95:814-7.

4. Holman WL, Murrah CP, Ferguson ER, Bourge RC, McGiffin DC, Kirklin JK. Infections during extended circulatory support: University of Alabama at Birmingham experience 1989 to 1994. Ann Thorac Surgery. 1996;61:366-73.

5. Holman WL, Park SJ, Long JW, Weinberg A, Gupta L, Tierney AR, et al. Infection in permanent circulatory support: experience from the REMATCH trial. J Heart Lung Transplant. 2004;23:1359-65.

6. Simon D, Fischer S, Grossman A, Downer C, Hota B, Heroux A, et al. Left ventricular assist device-related infection: treatment and outcome. Clin Infect Dis. 2005;40:1108-15.

7. Slater JP, Rose EA, Levin HR, Frazier OH, Roberts JK, Weinberg AD, et al. Low thromboembolic risk without anticoagulation using advanced-design left ventricular assist devices. Ann Thorac Surgery. 1996;62:1321-8.

8. Asai T, Baron HM, von Bayern MP, Sakaguchi T, Arrecubieta C, Cespedes CA, et al. A mouse aortic patch model for mechanical circulatory support. J Heart Lung Transplant. 2005;24:1129-32.

9. Tompkins DC, Hatcher VB, Patel D, Orr GA, Higgins LL, Lowy FD. A human endothelial cell membrane protein that binds Staphylococcus aureus in vitro. J Clin Invest. 1990;85:1248-54.

10. Yao L, Berman JW, Factor SM, Lowy FD. Correlation of histopathologic and bacteriologic changes with cytokine expression in an experimental murine model of bacteremic Staphylococcus aureus infection. Infect Immun. 1997;65:3889-95.

11. Ogawa SK, Yurberg ER, Hatcher VB, Levitt MA, Lowy FD. Bacterial adherence to human endothelial cells in vitro. Infect Immun. 1985;50: 218-24.

12. Sivaratnam K, Duggan JM. Left ventricular assist device infections: three case reports and a review of the literature. ASAIO J. 2002;48:2-7.

13. Salih V, Graham TR, Berry CL, Coumbe A, Smith SC, Dasse K, et al. The lining of textured surfaces in implantable left ventricular assist devices. An immunocytochemical and electronmicroscopic study. Am J Cardiovasc Pathol. 1993;4:317-25.
14. Spanier TB, Chen JM, Oz MC, Stern DM, Rose EA, Schmidt AM. Time-dependent cellular population of textured-surface left ventricular assist devices contributes to the development of a biphasic systemic procoagulant response. J Thorac Cardiovasc Surg. 1999;118:404-13.

15. Menconi MJ, Owen T, Dasse KA, Stein G, Lian JB. Molecular approaches to the characterization of cell and blood/biomaterial interactions. J Card Surg. 1992;7:177-87.

16. Frazier OH, Baldwin RT, Eskin SG, Duncan JM. Immunochemical identification of human endothelial cells on the lining of a ventricular assist device. Tex Heart Inst J. 1993;20:78-82.

17. Peacock SJ, Foster TJ, Cameron BJ, Berendt AR. Bacterial fibronectinbinding proteins and endothelial cell surface fibronectin mediate adherence of Staphylococcus aureus to resting human endothelial cells. Microbiology. 1999;145 Pt 12:3477-86.

18. Hamill RJ, Vann JM, Proctor RA. Phagocytosis of Staphylococcus aureus by cultured bovine aortic endothelial cells: model for postadherence events in endovascular infections. Infect Immun. 1986;54: 833-6.

19. Patti JM, Allen BL, McGavin MJ, Hook M. MSCRAMM-mediated adherence of microorganisms to host tissues. Annu Rev Microbiol. 1994;48:585-617.

20. Sinha B, Francois PP, Nusse O, Foti M, Hartford OM, Vaudaux P, et al. Fibronectin-binding protein acts as Staphylococcus aureus invasin via fibronectin bridging to integrin alpha5beta1. Cell Microbiol. 1999; $1: 101-17$.

21. Reddy K, Ross JM. Shear stress prevents fibronectin binding proteinmediated Staphylococcus aureus adhesion to resting endothelial cells. Infect Immun. 2001;69:3472-5.

22. Deng MC, Edwards LB, Hertz MI, Rowe AW, Keck BM, Kormos $\mathrm{R}$, et al. Mechanical circulatory support device database of the International Society for Heart and Lung Transplantation: third annual report-2005. J Heart Lung Transplant. 2005;24:1182-7.

23. Arrecubieta C, Asai T, Bayern M, Loughman A, Fitzgerald JR, Shelton CE, et al. The role of Staphylococcus aureus adhesins in the pathogenesis of ventricular assist device-related infections. J Infect Dis. 2006;193:1109-19.

24. Gordon RJ, Quagliarello B, Lowy FD. Ventricular assist devicerelated infections. Lancet Infect Dis. 2006;6:426-37. 